\title{
Distribution of suspended particulate matter at the equatorial transect in the Atlantic Ocean
}

\author{
Vadim Sivkov $^{1,2}$ and Ekaterina Bubnova ${ }^{1,2}$ \\ ${ }^{1}$ Shirshov Institute of Oceanology, Russian Academy of Sciences, 36, Nahimovskiy prospekt, Moscow, 117997, Russia \\ ${ }^{2}$ Immanuel Kant Baltic Federal University, Kaliningrad, 14, A. Nevskogo str., Kaliningrad, 236016, Russia
}

Correspondence: Ekaterina Bubnova (bubnova.kat@gmail.com)

Received: 18 May 2021 - Discussion started: 9 June 2021

Revised: 26 September 2021 - Accepted: 27 September 2021 - Published: 21 October 2021

\begin{abstract}
A suspended particulate matter distribution against a hydrographical background was studied at the oceanographic transect across the equatorial Atlantic in the year 2000. An area of abnormally high suspended matter volume concentrations was found above the Sierra Leone Rise in the entire water column (eastern part of the transect). The suggested explanation for the anomaly is based on the ballast hypothesis whereby solid particles are incorporated as ballast into suspended biogenic aggregates, leading to increased velocities of sinking. This occurs within the Northwest African upwelling area, where the plankton exposed to the Saharan dust abundance form a significant number of aggregates, which are later transported equatorward via the Canary Current. An intermediate nepheloid layer associated with the Deep Western Boundary Current was recorded from the South American Slope at depths of 3200-3700 to $4300 \mathrm{~m}$ above the Para Abyssal Plain. Antarctic Bottom Water enriched in suspended matter was found mostly in the troughs at $40-41^{\circ} \mathrm{W}$. It was detached from the bottom, coinciding with the core of the flow due to the bottom rise "dam" located up-stream. The grain size of particles along the entire transect has a polymodal distribution with $2-4$ and $8-13 \mu \mathrm{m}$ modes. The registered rise in percentage in some parts of the transect of the 7-21 $\mu \mathrm{m}$ sized particles suggests the presence of the well-known coarse mode $(20-60 \mu \mathrm{m})$ formed by aggregation of transparent exopolymer particles (mucus).
\end{abstract}

\section{Introduction}

Numerous studies have focused on characterizing the suspended particulate matter (SPM) during the past half a century. Modern understanding of the basic patterns of the SPM distribution in the ocean had emerged by the end of the $1980 \mathrm{~s}$ (Chester, 1990). The oceanic SPM spread may be depicted as a three-layer structure with the following layers: (a) a surface water, (b) a clear water minimum, and (c) a deep water (Biscaye and Eittreim, 1977; McCave, 1986; Chester, 1990). It was also indicated that the distribution of the SPM in oceans basically shows the interaction between the bottom sediments and abyssal waters movement, so SPM-rich benthic nepheloid layers (BNLs) coincide with pathways of the western boundary currents (Biscaye and Eittreim, 1977). The works of Armi (1978) and McCave (1983) pointed out the lateral advection of SPM, which occurs due to bottom mixed layers being detached from the slope and leads to thickening and layering of BNLs. There are also strong intermediate nepheloid layers (INLs) in the clear water minimum layer in some regions (Thorpe and White, 1988).

The Geochemical Ocean Sections Study (GEOSECS) introduced an early global description of suspended particle distribution in the ocean, using mostly data on SPM collected via filtration (Craig and Turekian, 1976). The threelayer model of the SMP concentration distribution was also successively described in Brewer et al. (1976) at a transect through the western Atlantic Ocean: high concentrations were found in surface and in rapidly moving bottom waters, while low concentrations were observed in the mid-water regions of the sub-tropical gyres.

The SPM plays a crucial role in both regulation of sea water composition and material transport throughout the en- 
tire water column, experiencing various processes, e.g. dissolution, decomposition, disaggregation, aggregation (Gardner et al., 1985a). It was shown by McCave (1975) that the SPM sizes follow a hyperbolic distribution with increases in fine particle abundance, whereas most of the particle flux to the bottom lies in the coarser size classes.

Sinking particles may remove the dissolved trace elements from the solution (Lal, 1977) and transport them to bottom sediments. The extent to which the behaviour of dissolved trace elements is dominated by suspended solids was referred to as the great particle conspiracy (Turekian, 1977).

The summary in Jeandel et al. (2015) shows that fine particles $(<53 \mu \mathrm{m})$ represent the vast majority of particles in the ocean. According to Sheldon et al. (1972) the size spectrum of small particles varies predictably both geographically and with depth. A linkage of strong BNLs and benthic storms with upper ocean dynamics was described in Gardner et al. (2018). Yet the full characterization of fine SPM distribution and composition in the ocean remains insufficiently studied due to the high research costs. Thus, research on transects of fine SPM distribution is still required.

The equatorial Atlantic is an area of increased oceanographic interest owing to the central position on the global circulation map. The aim of this study was to explain the distribution of fine SPM concentration and size spectra on a transatlantic oceanographic transect in the equatorial zone of the Atlantic Ocean (Ioffe-2000 transect). The hydrophysical and hydrochemical data (background for the SPM distribution) have been published in sufficient detail (Sokov et al., 2002; Sarafanov et al., 2007). The SPM data, on the contrary, have been published in far less detail (Sivkov et al., 2001) due to the fact that not all the peculiarities were in accordance with general knowledge (Biscaye and Eittreim, 1977), namely, high SPM concentrations in the clear water minimum layer in the open ocean of the Eastern Atlantic, which are not INL. Recent studies of the SPM distribution and evolution allowed us to explain the features of the SPM distribution obtained on the transect.

\section{Materials and methods}

A sublatitudinal transect (13-28 July 2000) between the continental slopes of Guinea and Brazil with 61 closely spaced stations was performed during the eighth cruise of the R/V Akademik Ioffe (Fig. 1) (Ioffe-2000). Additional surface samples of SPM were taken in the Northwest African upwelling zone (Cap Blanc area) just before the start of the main transect (10-11 July 2000). Sampling at the Ioffe-2000 transect was carried out using the CTD with rosette sampler, equipped with $5 \mathrm{~L}$ Niskin bottles, while the additional surface sampling was carried out using a plastic bucket.

The SPM volume concentration and particle size distribution were determined by the conductometric method via the Coulter counter (ZBI model) for 407 samples from the Ioffe-
2000 transect and 13 samples from the Cap Blanc area (Supplement 1$)$ ( $0.5 \mathrm{~mL}$ sample). The Coulter counter calibration was carried out using Coulter Electronics standard methodology using $5.96 \mu \mathrm{m}$ diameter latex particles. The $70 \mu \mathrm{m}$ aperture was used, which ensured counting of particles in the size range of 1.8-20.7 $\mu \mathrm{m}$. Concentration of particles (ppm by volume) and size distribution were calculated based on the assumption of particle sphericity. The absolute measurement error for the Coulter counter is $6 \%$ (Carder et al., 1974). The distributions of temperature, salinity, dissolved oxygen, and silicates on the transect (Sokov et al., 2002; Sarafanov et al., 2007) were used in relation to the SPM data. The temperature and salinity data were recorded via a Neil Brown MarkIII CTD profile (accuracy of measurements was $0.002{ }^{\circ} \mathrm{C}$ for temperature, 0.002 for salinity on the practical salinity scale). The temperature accuracy was determined via precruise and postcruise laboratory calibrations, and the salinity accuracy was calculated by comparison with the bottle data. Water samples for additional salinity measurements and silicate concentrations were obtained using the hydrological complex mentioned above at every station. The silicate concentrations were determined according to the standard method (Mullin and Riley, 1955) (with the accuracy better than $0.2 \mu \mathrm{mol} \mathrm{kg}^{-1}$ ) (Sokov et al., 2002; Sarafanov et al., 2007).

\section{Hydrographical settings}

\subsection{Upper ocean}

The upper levels of the equatorial Atlantic water structure are dominated by the presence of large-scale westward currents and eastward countercurrents (Fig. 2a). The northern part of the studied region includes an eastward-flowing North Equatorial Countercurrent (NECC) at depths of 0-100 m and the North Equatorial Undercurrent (NEUC) at depths between 100 and $300 \mathrm{~m}$ (Wilson et al., 1994; Bischof et al., 2003), a westward-flowing North Equatorial Current (NEC), and the South Equatorial Current (SEC) (Bourlès et al., 1999).

The North Brazil Current (NBC) is a major western boundary current in the Atlantic Ocean that transports water to the north across the Equator within the upper $300 \mathrm{~m}$ (Johns et al., 1998; Bischof et al., 2003). The North Brazil Current starts as a northern branch of water originating from the South Equatorial Current as it bifurcates near the Brazilian continental shelf at about $10^{\circ} \mathrm{S}$, which turns the South Equatorial Current to the north, and then it merges with the North Brazil Undercurrent (NBUC). The North Brazil Current passes the Equator, carrying Tropical Surface Water (TSW, surface mixed layer) at depths of $0-100 \mathrm{~m}$ and the upper part of South Atlantic Central Water (SACW) (100$500 \mathrm{~m}$ ). There is also Salinity Maximum Water on the boundary of these two water masses, which was formed in the central subtropical gyre (Stramma et al., 2005). General pat- 


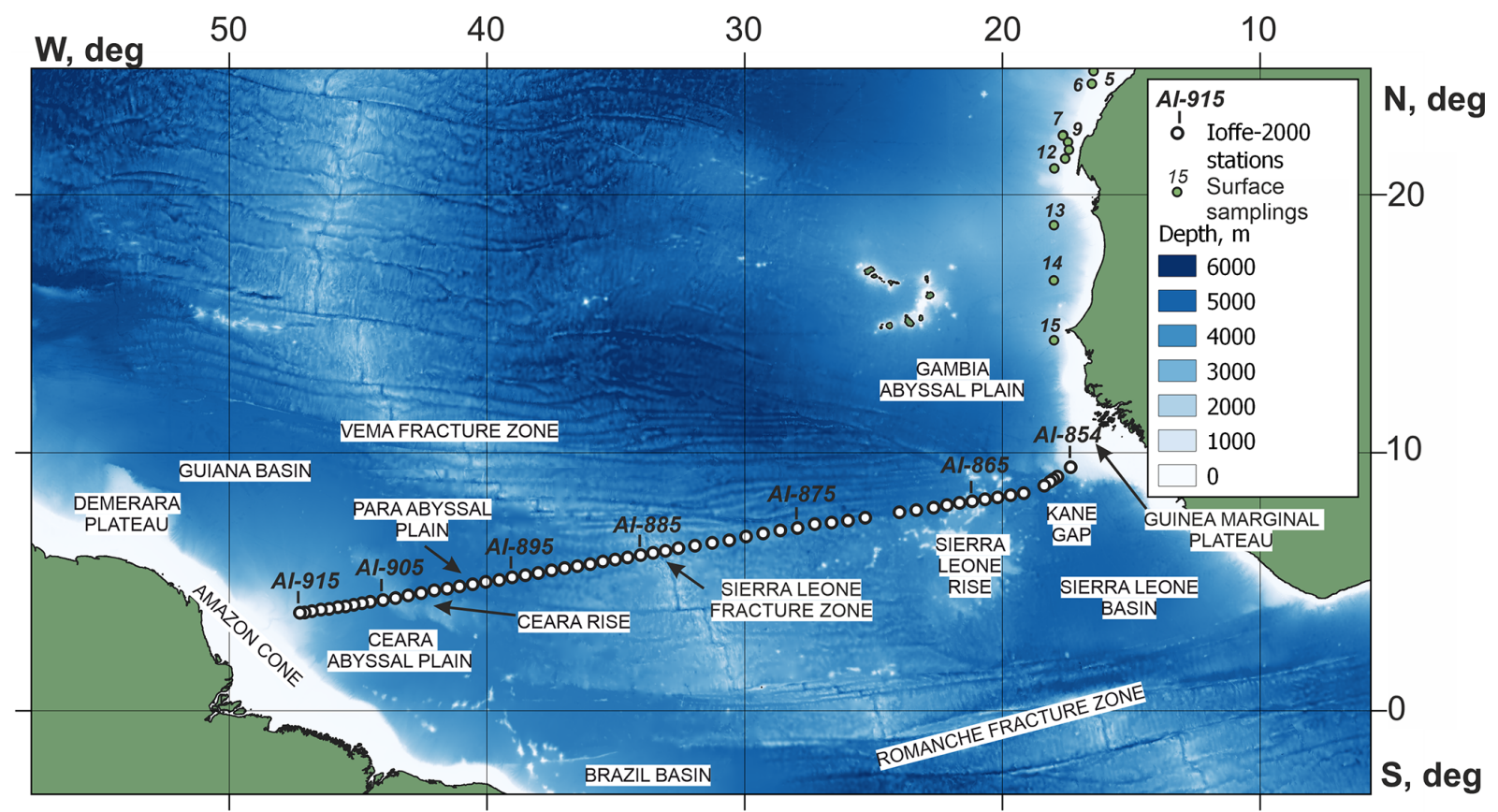

Figure 1. The Ioffe-2000 transect position in the study area (station numbers, every 10 stations). Bottom topography taken according to the GEBCO Bathymetric Compilation Group (2020).

terns of the western north equatorial circulation, according to Bruce et al. (1985), include a large anticyclonic eddy (diameter approximately $300-400 \mathrm{~km}$ ) at $7-10^{\circ} \mathrm{N}$ and a southern eddy-like feature $\left(3-6^{\circ} \mathrm{N}\right)$. Anticyclonic eddy features exist in the North Brazil Current up-stream from the retroflection (Johns et al., 1998) and they may propagate downstream within the North Brazil Current and serve as a catalyst for North Brazil Current ring shedding.

The North Brazil Current divides into both surface and subsurface layers of the North Equatorial Countercurrent/North Equatorial Undercurrent system (Wilson et al., 1994). There are three possible pathways for continuation of the North Brazil Current upper part $(0-100 \mathrm{~m})$ to the north: the coastal boundary current (Csanady, 1985; Candela et al., 1992), rings from the North Brazil Current retroflection (Didden and Schott, 1993; Richardson et al., 1994; Fratantoni et al., 1995; Johns et al., 1998), and offshore retroflection of the current into the North Equatorial Countercurrent (Mayer and Weisberg, 1993). The North Equatorial Countercurrent lies between 3 and $10^{\circ} \mathrm{N}$, roughly considered to be the northern boundary for the South Equatorial Current (Peterson and Stramma, 1991; Bourlès et al., 1999). Both the North Equatorial Countercurrent and the South Equatorial Current are the strongest from July to September and are also at their northernmost positions during this time (Peterson and Stramma, 1991). The retroflection of the North Brazil Current is considered to be the main source of the North Equatorial Countercurrent (Wilson et al., 1994; Bourlès et al., 1999; Schott et al., 2002), while additional sources for the latter are both the retroflected North Equatorial Current transport and the northern branch of the South Equatorial Current (Wilson et al., 1994). The thermocline North Brazil Current flow (in the $100-300 \mathrm{~m}$ layer) could also feed the North Equatorial Undercurrent between 2 and $5^{\circ} \mathrm{N}$ (Johns et al., 1998). Some of thermocline flow of the North Equatorial Undercurrent may also recirculate back into the North Brazil Current by means of the semipermanent anticyclonic "Amazon" eddy centred near $2^{\circ} \mathrm{N}$ (Bruce et al., 1985).

Caused by the Atlantic trade wind belt, the North Equatorial Current is found in the North Atlantic from about $7^{\circ} \mathrm{N}$ to about $20^{\circ} \mathrm{N}$ (Schott et al., 2002) and is a broad westward-flowing current that forms the southern limb of the North Atlantic subtropical gyre (Bourlès et al., 1999). The Guinea Dome (GD) is a permanent thermal upwelling dome (Rossignol and Meyrueis, 1964) centred at $9^{\circ} \mathrm{N}, 25^{\circ} \mathrm{W}$ and at $10.5^{\circ} \mathrm{N}, 22^{\circ} \mathrm{W}$ in boreal summer and winter respectively (Siedler et al., 1992). The main existence conditions for the Guinea Dome are a cyclonic circulation composed of the eastward North Equatorial Countercurrent and North Equatorial Undercurrent along with the westward-flowing North Equatorial Current (Stramma and Schott, 1999).

According to Mittelstaedt (1991), upon reaching the African coast, the North Equatorial Countercurrent bifurcates and a part of its flow goes northwards, forming the Mauritania Current (MC). The summer-early-autumn relaxation of the Northeast Trade winds (Lázaro et al., 2005) along with the North Equatorial Countercurrent strengthening are responsible for fact that the $\mathrm{MC}$ roughly reaches the $20^{\circ} \mathrm{N}$ 

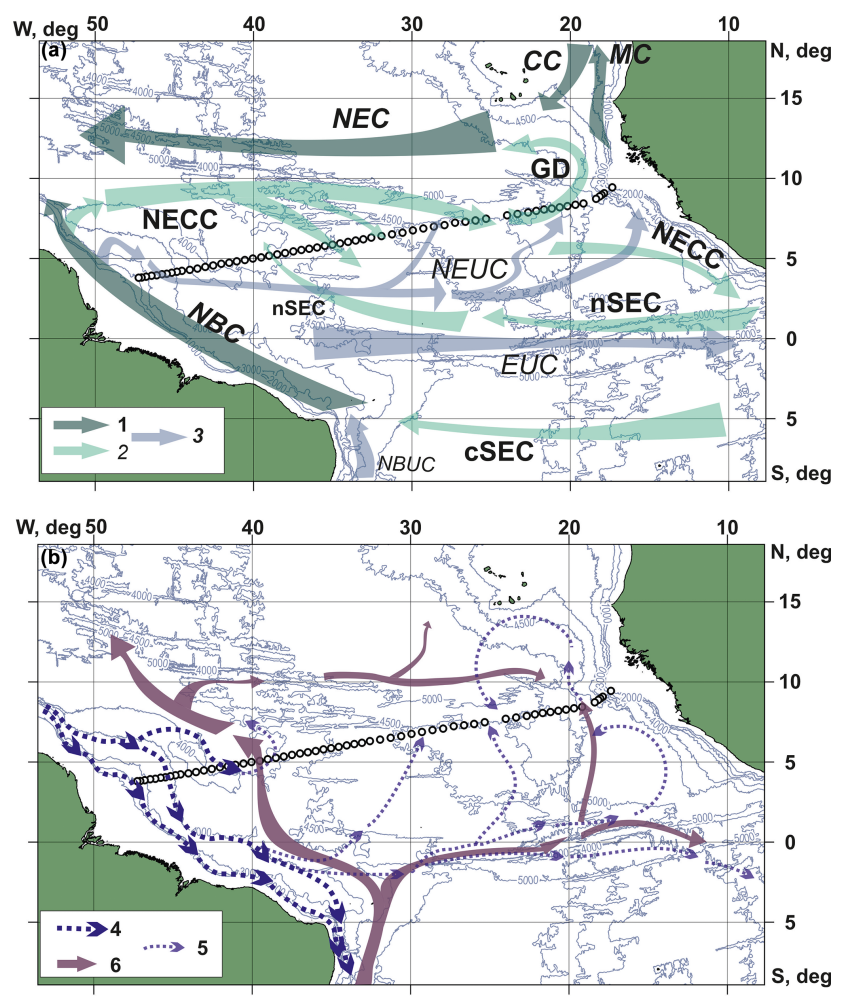

Figure 2. Generalized circulation schematics within the study area: surface and subsurface layers (a) and deep and bottom layers (b), where 1 denotes surface currents (from 0 up to $100 \mathrm{~m}$ ), 2 denotes subsurface currents (from 100 up to $500 \mathrm{~m}$ ), 3 denotes joint surface and subsurface currents (from 0 up to $500 \mathrm{~m}$ ), 4 denotes the Deep Western Boundary Current (DWBC) cores, 5 denotes schematic Deep Western Boundary Current recirculation, and 6 denotes Antarctic Bottom Water. The references and current abbreviations are explained in the text. White circles: Ioffe-2000 transect stations.

parallel, just south of Cap Blanc. This process is associated with the cessation of upwelling and the Canary Current (CC) in this area (Mittelstaedt, 1991; Stramma et al., 2008).

\subsection{Mid-depth ocean}

Intermediate waters, namely, Antarctic Intermediate Water (AAIW) and Upper Circumpolar Water (UCPW), cross the Equator northward mainly in the Western Atlantic between 500 and $1200 \mathrm{~m}$ depth (Oudot et al., 1999). The vertical minimum of potential temperature (Reid, 1997) and more so the intermediate maximum of silicate concentrations (Oudot et al., 1999) are distinguishing features of Upper Circumpolar Water in the equatorial zone. Antarctic Intermediate Water is carried by several interchanging eastward- and westward-flowing currents in the Equator area (Stramma and Schott, 1999; Brandt et al., 2006). Extended horizontal oxygen minimum zones exist in the eastern tropical Atlantic between 200 and $800 \mathrm{~m}$ due to microbial respiration of the large amounts of organic matter from the nearby North African upwelling area and weak water ventilation (Karstensen et al., 2008). The core of the North Atlantic oxygen minimum zone include South Atlantic Central Water and Antarctic Intermediate Water layers (Stramma et al., 2005). The major pathways to the northern oxygen minimum zones are subsurface eastward jet currents located south of $10^{\circ} \mathrm{N}$ : the Northern Intermediate Counter Current at $2^{\circ} \mathrm{N}$, the North Equatorial Undercurrent at $4^{\circ} \mathrm{N}$, and the northern branch of the North Equatorial Countercurrent at 8-9 $\mathrm{N}$ (Stramma et al., 2005; Karstensen et al., 2008; Brandt et al., 2010), while the core of the northern oxygen minimum zone lies further north. The link between these subsurface jet currents and the oxygen minimum zones is formed simultaneously by the cyclonic circulation around the Guinea Dome, a general uplift of the isopycnals within the surface and subsurface levels (Siedler et al., 1992; Lázaro et al., 2005).

\subsection{Deep ocean}

North Atlantic Deep Water (NADW) is formed in the North Atlantic by convection and mixing and transported southward. North Atlantic Deep Water penetrates into the Equatorial Atlantic at depths almost similar to the Deep Western Boundary Current and bifurcates into an eastward and southward flow, into the open ocean and along the western boundary, respectively (McCartney, 1993). According to Wüst (1935), upper North Atlantic Deep Water (UNADW) can be recognized by the mid-depth salinity maximum (1500-2000 m deep), while middle North Atlantic Deep Water (MNADW) at 2000-2500 m depth and North Atlantic Deep Water (LNADW) at $3700 \mathrm{~m}$ are recognized by the oxygen maxima. In Molinari et al. (1992), waters that had been recently ventilated are described as having had contact with the atmosphere either directly or indirectly by mixing on the timescale of the measurable transient tracer, chlorofluorocarbon. The highest values of one of these chlorofluorocarbons (F11: trichlorofluoromethane) are found in lower North Atlantic Deep Water (Rhein et al., 1998).

Two cores of recently ventilated (with higher levels of F11) North Atlantic Deep Water from the Northern Hemisphere are advected along the boundary and east to the Mid-Atlantic Ridge (Molinari et al., 1992). A Deep Western Boundary Current shallow core is centred at about $1500 \mathrm{~m}$ and a deeper one - at about $3500 \mathrm{~m}$. The upper core of high F11 content, limited by the 3.2 and $4.7^{\circ} \mathrm{C}$ potential temperature isotherms, is typically associated with the deeper core, which is limited by the 1.8 and $2.4{ }^{\circ} \mathrm{C}$ isotherms. The Ceara Rise blocks the flow of the Deep Western Boundary Current waters with potential temperature below $1.8^{\circ} \mathrm{C}$ to the Equator, causing it to recirculate back to the north (Fig. 3).

Denser Antarctic Bottom Water (AABW) flows northwards through Atlantic Ocean basins and generally lies beneath North Atlantic Deep Water at the bottom. The velocity field of Antarctic Bottom Water (water with $\sigma_{4}>$ 


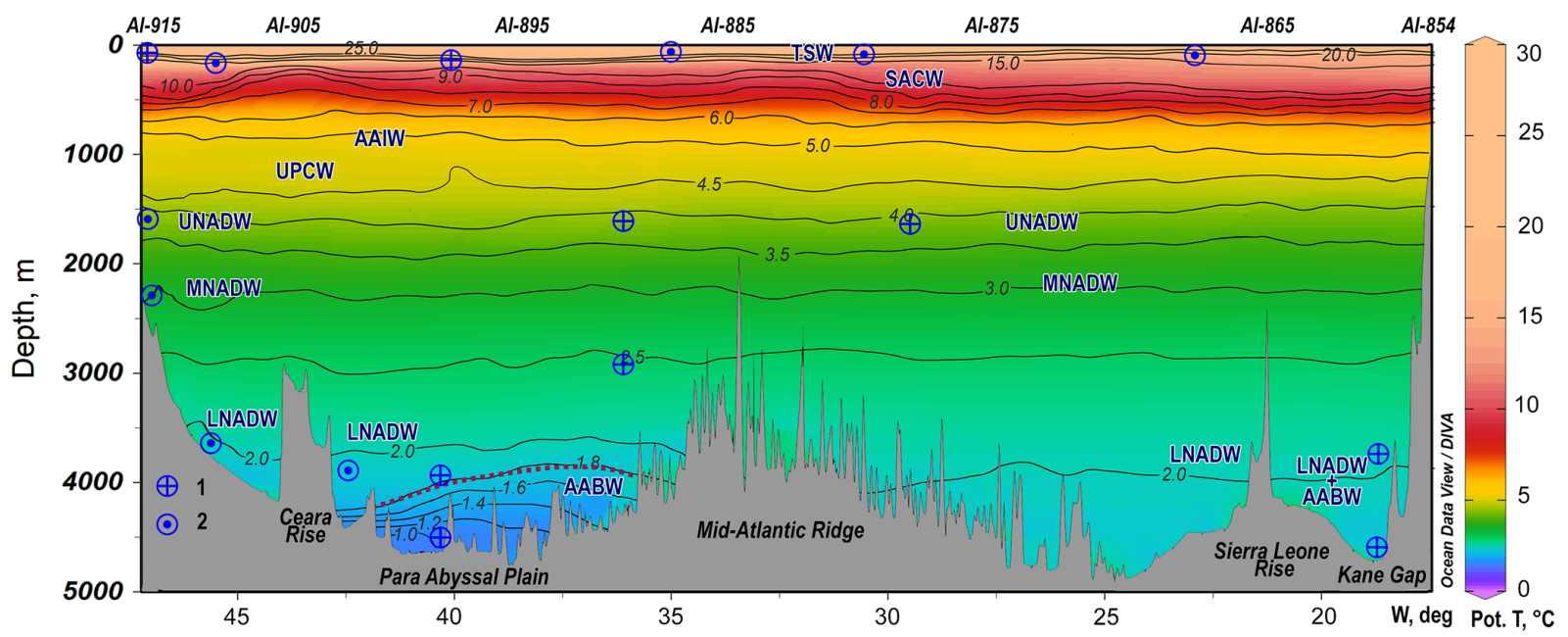

Figure 3. Distribution of the potential temperature $\left({ }^{\circ} \mathrm{C}\right)$ on the Ioffe-2000 transect (after Sokov et al., 2002), done with Ocean Data View (Schlitzer, 2018). Numbers indicated on the bottom left. 1: northward current, 2: southward current. For water mass abbreviations see text. Bottom topography after Sokov et al. (2002). The interpolation was done via the DIVA gridding (Barth et al., 2010) with $25 \%$ o $X$-scale length and $25 \%$ $Y$-scale length. Dashed magenta line indicates $\sigma_{4}>45.90 \mathrm{~kg} \mathrm{~m}^{-3}$.

$\left.45.90 \mathrm{~kg} \mathrm{~m}^{-3}\right)$ is influenced by the overlying Deep Western Boundary Current (Rhein et al., 1998) (see Fig. 3). The Antarctic Bottom Water is older than North Atlantic Deep Water and has low F11 concentrations (Touratier et al., 2005) or is even negligible in the Western Atlantic (Reid, 1994). According to Rhein et al. (1998), Antarctic Bottom Water bifurcates at the Equator: roughly $30 \%$ of the northward Antarctic Bottom Water flow comes to the Guiana Basin through the Equatorial Channel at $35^{\circ} \mathrm{W}$. A large proportion of Antarctic Bottom Water turns east through the Romanche Fracture Zone to the Eastern Atlantic, with a possible recirculation in the Brazil Basin. The sloping topography of the Guiana Basin as well as the limitation of the Antarctic Bottom Water upper boundary by the strong eastwardflowing North Atlantic Deep Water causes the northwarddirected geostrophic flow of Antarctic Bottom Water to be most pronounced only to the east of the Ceara Rise. Passing Ceara Rise, Antarctic Bottom Water flows to the central part of Guiana Basin. The high level of F11 (>0.07 pmol kg-1) from lower North Atlantic Deep Water affects the part of Antarctic Bottom Water closest to the Ceara Rise; thus this Antarctic Bottom Water branch also experiences a rise in F11 content in comparison with its far eastern branch. Similar conditions are found to the north of Ceara Rise (Rhein et al., 1998). According to Whitehead and Worthington (1982) and Rhein et al. (1998), the core of Antarctic Bottom Water is located to the east of Ceara Rise at $43.3^{\circ} \mathrm{W}$.

Antarctic Bottom Water mixes with lower North Atlantic Deep Water in the fracture zones at the Equator, so Antarctic Bottom Water in the Eastern Atlantic differs from the similar water in the Western Atlantic (Rhein et al., 1998). There are two important features for the Eastern Equatorial Atlantic (McCartney et al., 1991). First, the potential flow of Antarctic
Bottom Water through the Kane Gap from the Sierra Leone Basin to the Gambia Abyssal Plain and back, and second, the potential Antarctic Bottom Water flow through the Vema Fracture Zone.

According to Arhan et al. (1998) the eastward transport of North Atlantic Deep Water along the Equator is weak but nevertheless plays a leading role in the maintenance of the equatorial tongue of upper North Atlantic Deep Water. Even though the eastward mean velocities are weak in the equatorial tongues of North Atlantic Deep Water, the question is of the ultimate fate of this flow as it reaches the African continental slope. There are two cyclonic flows in the deep layers of the Eastern Atlantic, associated with North Atlantic Deep Water - those of the Gambia Basin and the Sierra Leone Basin.

\section{Results and discussion}

\subsection{SPM concentration}

The distribution of SPM within the Ioffe-2000 transect is presented in Fig. 4, while background hydrophysical and hydrochemical conditions were described in detail in Sarafanov et al. (2007). The measured volume SPM concentrations varied from 0.01 to $0.40 \mathrm{ppm}$ within the Ioffe-2000 transect and up to $4.1 \mathrm{ppm}$ at the stations at the Northwest African upwelling area. The work of McCave (1983) contains both the partly comparable dataset of SPM volume concentrations with a slightly wider size range $(1.26-32 \mu \mathrm{m})$, and the apparent particle densities, which lie between 1.65 and $2.23 \mathrm{mg} \mathrm{mm}^{-3}$. Applying these apparent densities to our volume SPM concentrations, we got the implied weight concentrations of about 0.016 to $0.35 \mathrm{mg} \mathrm{L}^{-1}$ (up to $0.8 \mathrm{mg} \mathrm{L}^{-1}$ in 
exceptional circumstances), which agrees with Brewer et al. (1976) and Gardner et al. (1985a).

\subsubsection{Upper ocean}

In the upper layers, most commonly, the vertical distribution of SPM has a surface maximum, decreasing exponentially towards the deep. The main reason for this is the fact that the upper ocean contains both the external SPM sources (river discharge, atmospheric input) and the internal SPM sources (primary production) (Chester, 1990). Another reason for particle accumulation in the surface layer may be the pycnocline, which slows the sedimentation (Emelyanov, 2005). Accumulation in the surface layer may be the existence of the pycnocline at the bottom of the surface layer, which slows the sedimentation. The "sedimentation barrier" can be seen as a visible pycnocline at depths of $50-150 \mathrm{~m}$ to the west of the $30^{\circ} \mathrm{W}$ and $0-100 \mathrm{~m}$ to the east of this point on the Ioffe-2000 transect (Sarafanov et al., 2007). It was shown for the Eastern Equatorial Atlantic that the largest particulate elemental and mass concentration gradient occurs at the base of the mixed layer, where the particle and organism maximums are located. The source of the vast majority of particles in the upper open ocean waters is internal and basically consists of particulate organic matter (POM), $\mathrm{CaCO}_{3}$, and biogenic silica. A large proportion of the POM produced in surface waters is regenerated in the euphotic zone. Although the net transport of organic matter has to be downward to fuel the lower layers of the water column, there is also an upward component to transport. Positively buoyant particles, including lipid-rich eggs, larvae, and, possibly, carcasses of deep-sea animals are examples of particles which undergo upward transport (Smith et al., 1989).

The Ioffe-2000 transect did not reach the SPM-rich shelf waters, yet the coastal SPM source has caused a local SPM maximum at the margins of the transect at a depth of 300$900 \mathrm{~m}$ (up to $0.18 \mathrm{ppm}$ in the west and up to $0.09 \mathrm{ppm}$ in the east). The eastern edge of the Ioffe-2000 transect is located above the gentle slope between 200 and $2000 \mathrm{~m}$ named Guinea Marginal Plateau (Egloff, 1972), adjacent to the high productive Guinea shelf (Vladimirov et al., 1990; Burlakova et al., 1997). Strong currents (Mittelstaedt, 1991; Stramma et al., 2005, 2008) and implied internal wave activity, based on significant density gradients on the shelf (0$200 \mathrm{~m}$ ) (Sarafanov et al., 2007), may provide a framework for the SPM lateral transport from the shelf along the gentle plateau slope. It was the Amazon River that caused the more pronounced rise in SPM concentration at the western edge of the transect. It is well-known that the surface SPM transport from the Amazon River to the open ocean turns to the northeast alongside the coast (Gibbs, 1974). According to Sarafanov et al. (2007), the warm, high-saline, and silicatepoor upper waters observed on the Ioffe- 2000 transect above 400-500 m were advected mostly by the North Brazil Current. The North Brazil Current core was located immediately westward of the studied transect near the shelf break (Johns et al., 1998). A signature of the North Brazil Current eastern periphery is located between 46 and $47^{\circ} \mathrm{W}$ at depths of 150-500 m (Sarafanov et al., 2007). The SMP concentrations within the North Brazil Current are relatively low (stations AI-910-AI-912). The main evidence of the SPM supply from the Amazon River to the shelf and the continental slope is a huge sediment body - the Amazon Cone. Bottom SPM maxima of Amazon River origin are able to form INL falling from the shelf break. INLs are mostly caused by the detachment of BNLs over the breaks in the slope (McCave et al., 2001). One of the INLs was apparently observed during the Ioffe-2000 transect as a significant rise in the SPM concentration below the North Brazil Current.

Sarafanov et al. (2007) shows the North Equatorial Undercurrent equatorward pathway at $44-46^{\circ} \mathrm{W}$. We have suggested that such $\mathrm{V}$-shaped isopycnals at $46^{\circ} \mathrm{W}$ between the North Brazil Current and North Equatorial Undercurrent (Sarafanov et al., 2007, Fig. 3A) correspond with the aforementioned large eddy-like feature, the semi-permanent "Amazon Eddy" (Bruce et al., 1985).

The northern branch of the South Equatorial Current (nSEC) is associated with the northwestward or northward near-surface flow at $38-41^{\circ} \mathrm{W}$, which recirculates northward into the North Equatorial Countercurrent. Probably, the local surface maximum of the SPM concentration at $44^{\circ} \mathrm{W}$ was caused by the northern branch of the South Equatorial Current and North Equatorial Countercurrent convergence. The surface SPM maximum was also noted in the most intense cross-transect flow of the North Equatorial Countercurrent at 35-37 W (Sarafanov et al., 2007).

The eastward rise of the isopycnals at $28-25^{\circ} \mathrm{W}$ and their deepening at $24.5-21.5^{\circ} \mathrm{W}$ at $150-500 \mathrm{~m}$ indicates the southern periphery of the Guinea Dome on the Ioffe-2000 transect (Sarafanov et al., 2007, Fig. 3A). Immediately east of the Guinea Dome $\left(21.5-18^{\circ} \mathrm{W}\right)$ the S-shaped double rotation (a combination of the cyclonic and anticyclonic structures) of the North Equatorial Undercurrent (Stramma et al., 2008, Fig. 12) occurred. It is known that the Guinea Dome influences biological activity, so the chlorophyll $a$ concentration is high in this region and linked to the intensity of the doming (Signorini et al., 1999; Pradhan et al., 2006; Doi et al., 2009). The local SPM maximum below the Guinea Dome area within the Ioffe-2000 transect agrees with this data. Overall, the SPM distribution within the Ioffe-2000 transect's upper layer mainly reflects surface circulation patterns (Biscaye and Eittreim, 1977) as well as particle transport (vertical and horizontal).

\subsubsection{Mid-depth ocean}

According to Sarafanov et al. (2007), the intermediate waters on the Ioffe-2000 transect were recorded as an area low in salinity and rich in silicate waters, which extends at depths of 400-1200 m. The main Antarctic Intermediate Water en- 


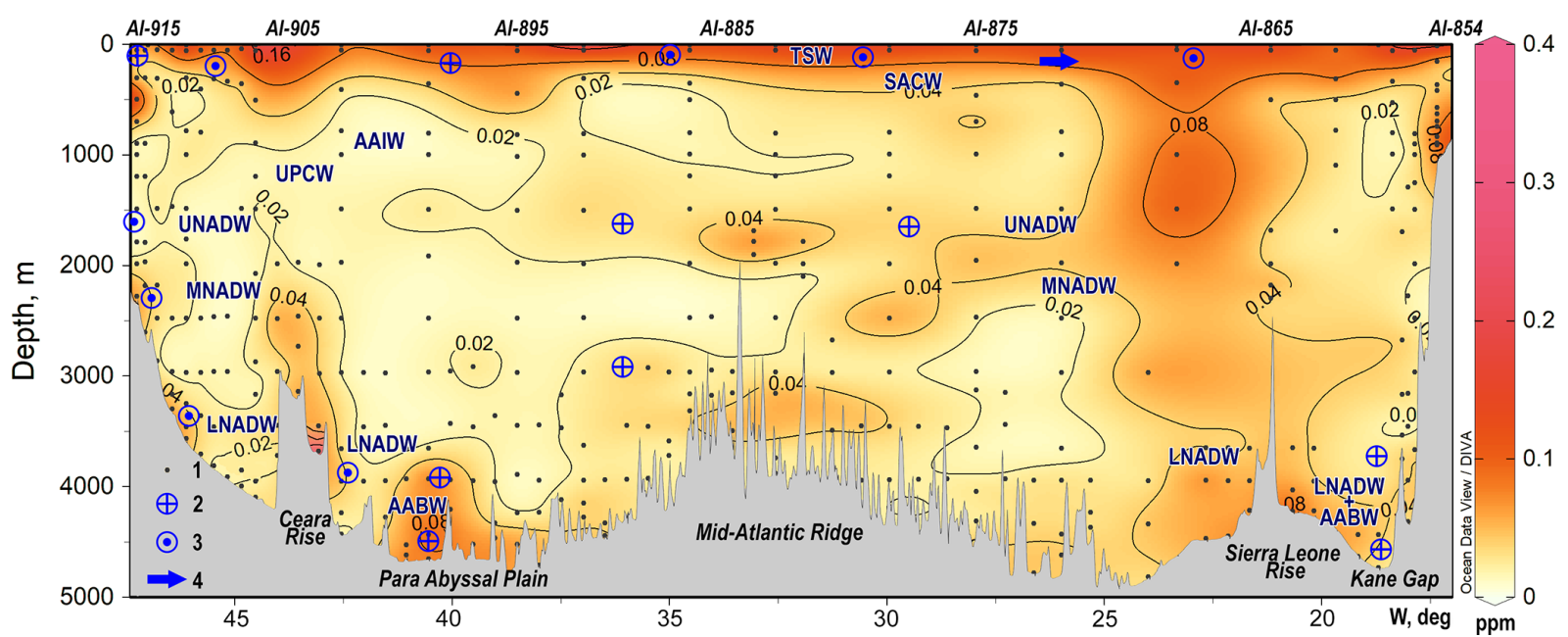

Figure 4. Distribution of the SPM volume concentration (ppm) on the Ioffe-2000 transect, done with Ocean Data View (Schlitzer, 2018). Numbers indicated on the bottom left: 1 denotes sampling points, 2 denotes northward current, 3 denotes southward current, 4 denotes eastward current. Isolines are in geometric progression, for water mass abbreviations see text. Bottom topography similar to Sokov et al. (2002). The interpolation was done via the DIVA gridding (Barth et al., 2010) with $25 \%$ o $X$-scale length and $65 \%$ o $Y$-scale length.

trance to the Northern Hemisphere is located in the western part of the transect (west of $36^{\circ} \mathrm{W}$ ). Neither Antarctic Intermediate Water nor Upper Circumpolar Water come along the Brazilian slope while flowing from the western equatorial basin to the tropical North Atlantic but rather flow in the interior ocean.

Usually the intermediate waters correspond with the upper part of the clear water minimum. Clear water is referred to the minimum in the SPM concentration that is commonly located above the BNL (Eittreim and Ewing, 1974; Biscaye and Eittreim, 1977). Concentrations of the SPM within this layer are 10-100 times lower than in the upper ocean but still reflect, in general, a similar geographic distribution with high values in the coastal zone and the lowest values at the open ocean. As was mentioned above, the clear water layer SPM concentrations reflect, also, the lateral supply of the SPM from the coastal areas (Biscaye and Eittreim, 1977). However, the intermediate waters on the Ioffe-2000 transect were not influenced by the lateral source too strongly, so the SPM concentrations were low (0.01-0.03 ppm).

On the contrary, the wide area below the Guinea Dome $\left(19-25^{\circ} \mathrm{W}\right)$ is noteworthy due to extremely high SPM concentrations for this clear water layer, which primarily reflects the pattern of productivity in the upper waters (Eittreim et al., 1976). We suggest that this SPM-rich area was caused by the extra high bioproductivity levels within the Northwest African upwelling (Fig. 5) and, probably, the Guinea Dome area. The recent studies of the Guinea Dome (Bubnova et al., 2020) surface layer showed high SPM concentrations (from 0.1 and even up to $0.7 \mathrm{mg} \mathrm{L}^{-1}$ ) for the low season of the Guinea Dome development. Equatorward transport of the POM is carried out by the interaction of the $\mathrm{CC}$ and the aforementioned system of equatorial currents. An additional

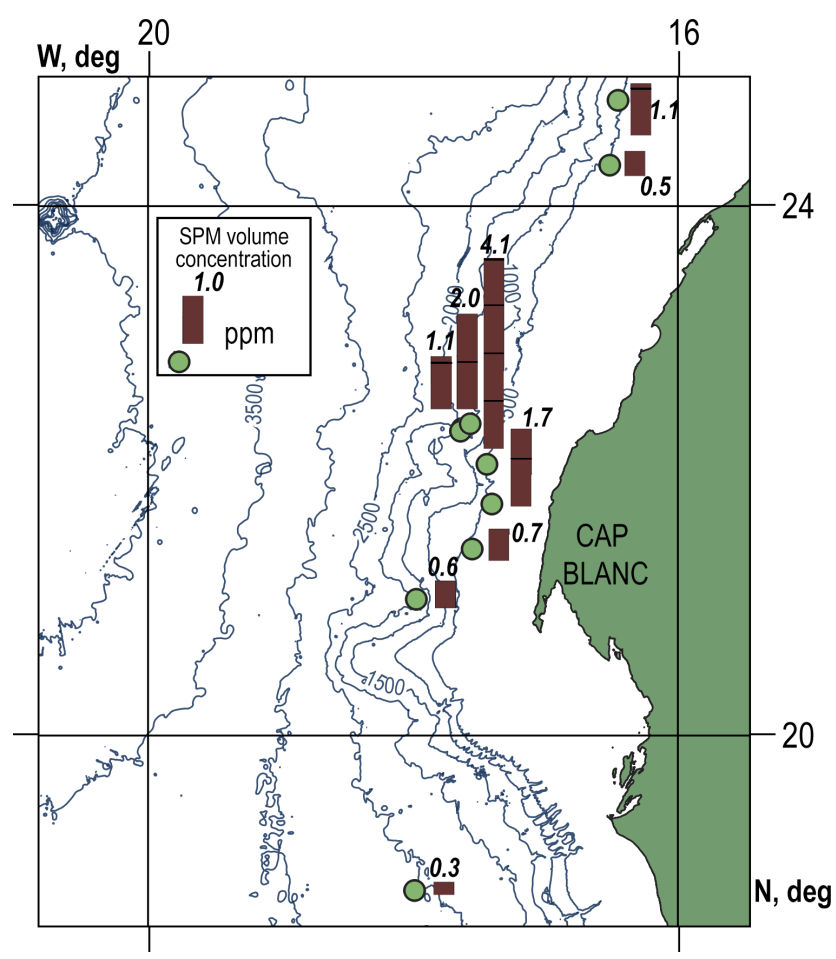

Figure 5. Schematic distribution of surface SPM concentrations (ppm) in the Northwest African upwelling area prior to the Ioffe2000 transect. Isobaths every $500 \mathrm{~m}$. 
explanation for the POM supply is the low dissolved oxygen level (oxygen minimum zones signature), which was observed at 300 to $700 \mathrm{~m}$ depth at about $20-25^{\circ} \mathrm{W}$ and further westward to the Mid-Atlantic Ridge (Sokov et al., 2002). Not only is the oxygen minimum caused by the POM supply, but it also prevents organic particle destruction.

\subsubsection{Deep ocean}

It is known that the vertical and zonal structure of the deep and bottom waters, i.e. North Atlantic Deep Water and Antarctic Bottom Water, in the Eastern Atlantic are significantly more homogeneous than in the Western Atlantic. The Eastern Atlantic generally shows low turbidity (SPM concentration) levels within the North Atlantic Deep Water and Antarctic Bottom Water in comparison with the Western Atlantic (Eittreim et al., 1976). The AABW transport in the deep layers of Eastern Atlantic is almost negligible in comparison with the intense northward flow of Antarctic Bottom Water to the east of the Ceara Rise in the western basin, which was noted during the Ioffe-2000 transect (Sarafanov et al., 2007).

The Eastern Atlantic. The research to the east of MidAtlantic Ridge at the Ioffe-2000 transect allowed us to note two peculiarities. The first one was the northward North Atlantic Deep Water flow through the Kane Gap into the Gambia Basin, while the second one pointed out the dominance of lower North Atlantic Deep Water in the near-bottom layer west of the Sierra Leone Rise.

The deep waters correspond with the lower part of the clear water minimum. However, abnormally high SPM concentrations for these depths were noted above the Sierra Leone Rise (Fig. 4). This SPM concentration anomaly was connected with another above it in the mid-depth ocean. There is also a slight horizontal "tail" with increased SPM concentration spreading almost to the Mid-Atlantic Ridge. The probable reason for the existence of the "tail" is the cyclonic flow over the Gambia Abyssal Plain (Arhan et al., 1998). We explain this "vertical anomaly" by using the ballast hypothesis (Armstrong et al., 2001; Louis et al., 2017), which is based on the correlation between the fluxes of particulate organic carbon (POC) and minerals in the deep ocean. According to hypothesis description in Van der Jagt et al. (2018), biogenic aggregates are ballasted with biogenic and lithogenic minerals, so their sinking velocities increase. Minerals start to get attached to aggregates both in the surface layer and deeper: during the aggregate formation or when aggregates "scavenge" mineral particles while sinking. The fact that ballasted aggregates sink with higher speed is the main reason for them to be remineralized at a greater depth in comparison with non-ballasted aggregates. Different aggregates are incorporated with different numbers of minerals due to different levels of stickiness, which is controlled by the amount of transparent exopolymer particles (Alldredge et al., 1993). Precursors of transparent exopoly- mer particles are produced mainly by phytoplankton (Passow and Alldredge, 1994). The amount of transparent exopolymer particles in the ocean is huge; they occur as "sticky" gels (Passow, 2002), so transparent exopolymer particles act as a glue matrix for other solid particles (i.e. detritus), forming larger aggregates ("marine snow") and playing a crucial role in the carbon export from the surface to the deep ocean (Passow et al., 2001).

The SPM in regions with high external supply (for example, the North Atlantic), which have high sedimentary dust inputs, consists mostly of lithogenic material. For instance, the surface waters off Cap Blanc (Iversen and Ploug, 2010) and Guinea Dome (Bubnova et al., 2020) are exposed to the Saharan dust. The Saharan dust deposition may cause the abiotic formation of transparent exopolymer particles, which results in the aggregate formation and enhancing the POC export (Louis et al., 2017). Dust is able to ballast into marine snow aggregates (and fecal pellets) and it also increases the oceanic primary production due to input of dust-related micronutrients (Van der Jagt et al., 2018). The strength of the so-called "lithogenic carbon pump" (Bressac et al., 2014) potentially depends on the physical and chemical precursors of transparent exopolymer particles featured, which, in turn, stand on the composition and physiological state of the phytoplankton community. The Northwest Africa offshore zone shows high levels of primary production and SPM concentrations (Fig. 5). This area is also exposed to abundant Saharan dust input. The resulting large number of ballasted aggregates is then transported equatorward via the $\mathrm{CC}$ and consistent flow of the North Equatorial Current, North Equatorial Countercurrent, and Guinea Dome (equatorial currents system), reaching the Ioffe-2000 transect area.

The Van der Jagt et al. (2018) study showed that the total volume of aggregates increased 10 times due to dust deposition, while size-specific sinking velocities of the dustballasted aggregates doubled. It was also shown that the dust-ballasted aggregates carried only $50 \%$ of the volumetric POC amount in comparison with non-ballasted aggregates. Thus, the overall POC flux driven by dust deposition may rise up to 10 times due to the abundance of aggregates. As we remember, fast-sinking aggregates are remineralized deeper leading to an increase in the POC fluxes to the deep sea layers (Van der Jagt et al., 2018), which preserves the high SPM concentrations down to the deep ocean. Such fastsinking ballasted aggregates, which were transported from the Northwest Africa upwelling area, caused the abnormally high SPM concentrations above the Sierra Leone Rise in the Ioffe-2000 transect.

The Western Atlantic. The vast area to the west of the MidAtlantic Ridge within the Ioffe-2000 transect showed higher (in comparison with the Eastern Atlantic) values of SPM concentrations, caused by Deep Western Boundary Current. It is well-known that there are two reasons for the bottom currents to maintain high loads of SPM: potential resuspension and, far more importantly, selective deposition. The SPM may 
be transported far within the BNLs, as was shown for clay minerals (Petschick et al., 1996). The most intense BNLs in the western Atlantic are found in the southwestern Argentine Basin and northern North American Basin; while the lowest bottom water turbidity is located in the equatorial regions (Eittreim et al., 1976; Biscaye and Eittreim, 1977). Nevertheless, bottom SPM concentrations west of the Mid-Atlantic Ridge are still higher in comparison with the eastern part of the Equatorial Atlantic. According to Sarafanov et al. (2007), the southward boundary flow of Upper North Atlantic Deep Water was traced in the western basin along the continental slope at the depths of 1400-1500 m. Middle North Atlantic Deep Water southward flow was noted at 1900-2600 m with the $100 \mathrm{~km}$ wide recirculation. The general lower North Atlantic Deep Water flow was noted at $3700 \mathrm{~m}$ depth. The deep cyclonic cell in the Guiana basin (McCartney, 1993; Arhan et al., 1998) at North Atlantic Deep Water depth is located near the Ceara Rise western slope and west of the Mid-Atlantic Ridge between 42 and $36-37^{\circ} \mathrm{W}$. This northward recirculation of lower North Atlantic Deep Water joins the northward flow of Antarctic Bottom Water.

The noticeable BNL in the western basin is located at 1900-2600 m above the American slope (the Amazon Cone). We suggest that the main reason for its occurrence is the interaction between the shallow core of the Deep Western Boundary Current and the Amazon River solid load.

The weak INL deepening from the slope to the east was noted at a depth of 3200-3700 m (Fig. 6). It is enhancing above the Ceara Rise as a result of the Deep Western Boundary Current intensification due to the interaction with bottom topography. This INL can be traced to the east from the Ceara Rise ( $4300 \mathrm{~m}$ depth and $42.5^{\circ} \mathrm{W}$ ), where the deep Deep Western Boundary Current core is marked by high F11 levels.

The main reason for the SPM concentration rise at the depth of $3500-4300 \mathrm{~m}$ between 41.5 and $39^{\circ} \mathrm{W}$ with the peak at $40.5^{\circ} \mathrm{W}$ is the northward recirculation of SPM-rich lower North Atlantic Deep Water.

The general northward pathway of Antarctic Bottom Water $\left(\sigma_{4}>45.90 \mathrm{~kg} \mathrm{~m}^{-3}\right)$ across the Ioffe-2000 transect is located in the Para Abyssal Plain bottom layer. An Antarctic Bottom Water core was found in the $40-42^{\circ} \mathrm{W}$ troughs, flowing along the Ceara Rise eastern slope (Sarafanov et al., 2007). Studies (Whitehead and Worthington, 1982; Rhein et al., 1998) show the Antarctic Bottom Water core to be separated from the bottom and located at a depth of 4400$4500 \mathrm{~m}$. Antarctic Bottom Water has high SPM concentrations in comparison with the clear water layer, mostly in the $40-41^{\circ} \mathrm{W}$ troughs. The SPM concentration maximum within Antarctic Bottom Water (Fig. 6) is aligned with the Antarctic Bottom Water core separated from the bottom (4400$4500 \mathrm{~m}$ ). The reason for the separation may be the bottom rise ("dam"), which is located up-stream from Antarctic Bottom Water flow (Whitehead and Worthington, 1982). The "dam" blocks the lower part of Antarctic Bottom Water flow and coinciding BNL at the depth of $4500 \mathrm{~m}$, creating the INL from BNL. One of the most notable similar nephelometric features was described for the Puerto Rico Trench near the Navidad sill (Tucholke and Eittreim, 1974). The BNL to the east of the Antarctic Bottom Water flow core is likely caused by Antarctic Bottom Water southward recirculation (Sarafanov et al., 2007).

The extremely high SPM concentration $(0.36 \mathrm{ppm})$ was noted in the bottom layer above the Ceara Rise (AI-903, depth $3678 \mathrm{~m}, 18 \mathrm{~m}$ above the bottom). The potential reason for that may be interaction between the SPM-rich Deep Western Boundary Current and a local feature in the bottom topography. Figure 7 shows that station AI-903 is near the terrace break $(3800 \mathrm{~m})$. The terrace slope has a low angle $\left(0.7^{\circ}\right)$, while below the terrace break lies a far steeper $\left(3.1^{\circ}\right)$ slope (3800-4300 m). This $15 \mathrm{~km}$ wide area with the steep incline perturbs the homogeneity of the Deep Western Boundary Current core: the part of the current above the flat terrace slows down, while the steeper slope causes a higher bottom current speed (Bowden, 1960). The current slow-down above the terrace is able to cause an eddy. The V-shaped terrace (see $3700 \mathrm{~m}$ isobath) allows the assumption that this eddy is the topographically trapped one. The eddy originating from the SPM-rich Deep Western Boundary Current causes an additional SPM concentration boost near the bottom. The proposed hypothesis undoubtedly needs to be confirmed by additional research.

The Mid-Atlantic Ridge area. High levels of the SPM concentration were also noted above the Mid-Atlantic Ridge (Fig. 4). There is the northward recirculation of North Atlantic Deep Water rich in the SPM (Sarafanov et al., 2007), which was noted both sides of the Mid-Atlantic Ridge at 3640 and $29-32^{\circ} \mathrm{W}$. Another type of current in the area is the tidal current (Morozov, 2018). According to Lavelle (2012), both these currents may be accelerated along the flanks of the ridge and represent a significant stirring mechanism for abyssal flow and cause the SPM concentration rise. Moreover, the axial region of the Mid-Atlantic Ridge including the rift zone experiences high seismicity and bears a large number of earthquake epicentres as well as the sulfide mineralization zones of various origins and bedrock zones showing strong hydrothermal imprints (Mazarovich and Sokolov, 2002), in particular in the Sierra Leone fracture zone, i.e. immediately below the Ioffe-2000 transect (see Fig. 1). Both high seismicity and strong hydrothermal activity may also be able to cause increased SPM concentrations in the bottom layer.

\subsection{Grain-size of the SPM}

The size distribution of suspended particles is generally considered to be a function of the source and nature of the particles, processes of aggregation, and the "age" of the suspension (McCave, 1983, 1985). SPM grain sizes in cumulative number distributions from the Ioffe-2000 transect follow a 


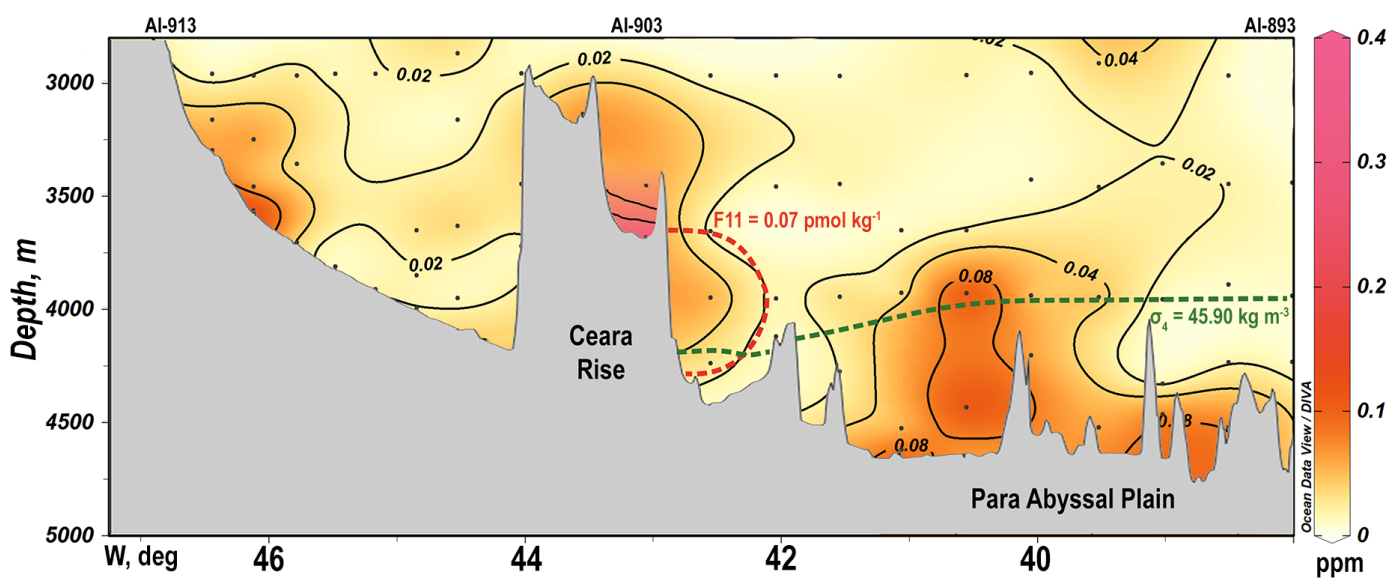

Figure 6. The SPM volume concentration at the western part of the Ioffe-2000 transect (magnified part with more detail of the Fig. 4): green dashed line denotes the upper boundary of Antarctic Bottom Water; red dashed line denotes the Deep Western Boundary Current boundary, based on the F11 (after Rhein et al., 1998, $4.5^{\circ} \mathrm{N}$ transect). Isolines in geometric progression.

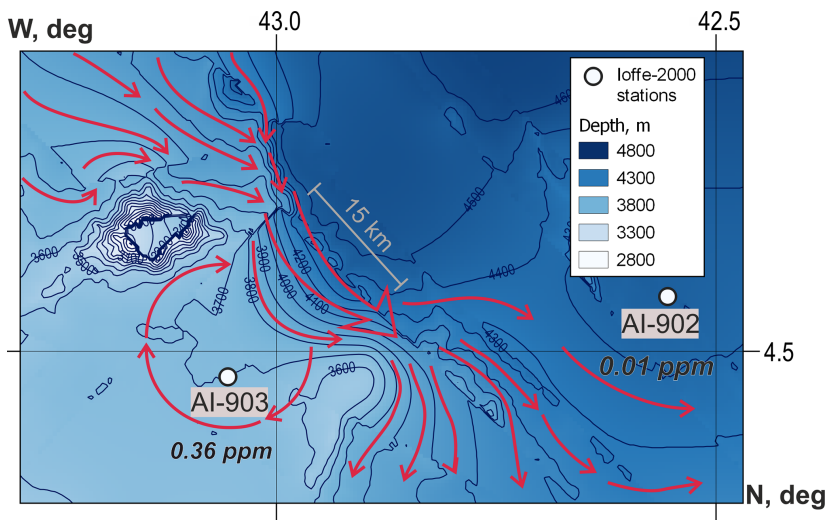

Figure 7. The Ceara Rise SPM maximum: bottom topography (GEBCO Bathymetric Compilation Group, 2020) and the Deep Western Boundary Current (red lines).

hyperbolic Junge distribution with slopes between -1.9 and -3.7 (Fig. 8), which correspond with McCave (1975), where slopes were mainly between -2.4 and -3 .6. The difference occurs due to the fact that McCave (1975) had a wider size spectrum. The overall cumulative number distribution for the Ioffe-2000 transect was recorded as a wavy line with an overall slope of approximately -2.7 , which is similar to McCave $(1984,1986)$ and Nowell et al. (1985).

One of the first detailed analyses of the SPM volume-size distributions was conducted during the HEBBLE project in abyssal waters (the Nova Scotia Rise, 1977-1984) (McCave, 1983; Nowell et al., 1985; McCave, 1985). The sizes measured by a Coulter counter in this project mainly showed the bimodal structure with a fine mode between 2 and $10 \mu \mathrm{m}$ and a coarse mode between 20 and $60 \mu \mathrm{m}$.

Since the Coulter counter aperture-tube truncation during the Ioffe-2000 was $70 \mu \mathrm{m}$, it was impossible to count parti-

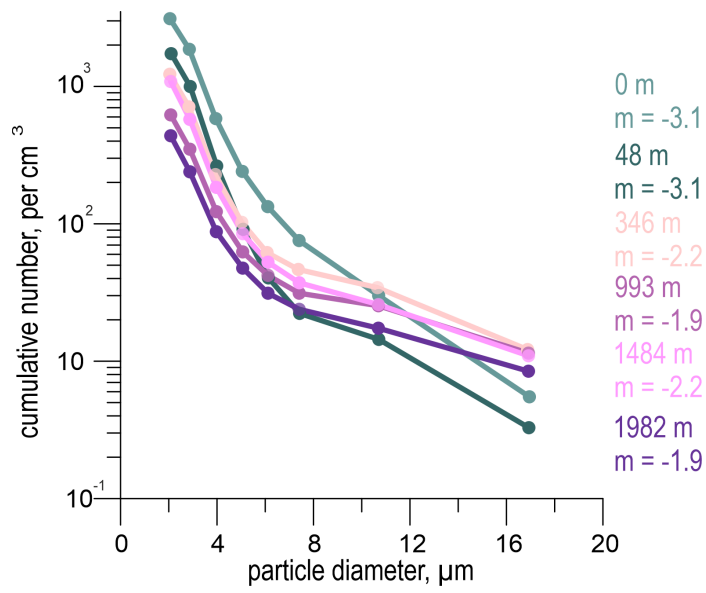

Figure 8. Cumulative particle number distribution for AI-868 station showing both "old" suspension in the upper ocean with the slope of the distributions close to -3 and "fresh" in the water column with steep slopes about -2 . Station AI-868 is a part of the SPM-rich "vertical anomaly". The $x$ axis is particle diameter; the $y$ axis is cumulative particle number in $\log 10$ scale.

cles up to $32 \mu \mathrm{m}$, so only the "left" part of the coarse mode is visible in Ioffe-2000 data (Fig. 9). The volume-size distributions display (a) an elevated proportion of the 7-21 $\mu \mathrm{m}$ fraction, suggesting the coarse mode; (b) a fine-mode with the peak size ranges about $2-4 \mu \mathrm{m}$; and (c) an intermediate mode at $8-13 \mu \mathrm{m}$ that was not mentioned in the HEBBLE project.

The most representative bimodal volume-size distributions in our study are shown in Fig. 9. According to McCave $(1983,1984)$, there are two most effective physical mechanisms for changing the size distributions: aggregation of small particles (below 1.5-8 $\mu \mathrm{m}$ ) by Brownian motion and collection of smaller particles by turbulent agitation with 


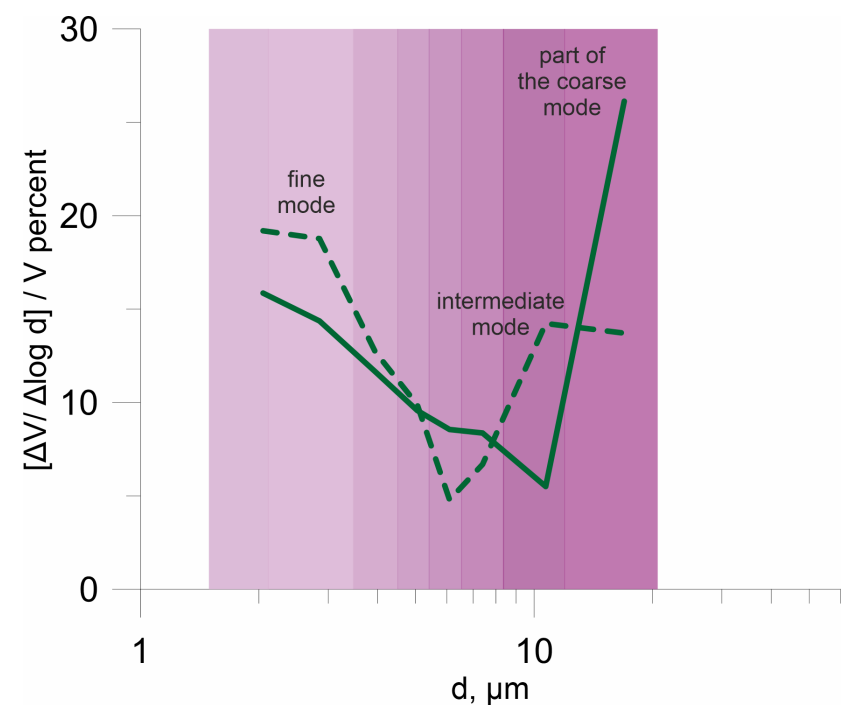

Figure 9. The typical examples of the bimodal volume-size SPM distribution. The $x$ axis is particle diameter; the $y$ axis is probability density function. Green solid line - dominance of aggregates (station AI-903, 3678 m); dashed green line - intermediate mode, caused mostly by phytoplankton, detritus and transparent exopolymer particles (station AI-887, $3717 \mathrm{~m}$ ). Size intervals are marked with colour.

larger particles. Thus, the fine mode mainly consists of aggregates. The more turbid suspensions according to Gardner et al. (1985b) contain a coarser fine mode $(\sim 8 \mu \mathrm{m})$ than the lower concentration suspensions with a mode of $2-3 \mu \mathrm{m}$. According to McCave (1984), the oceanic particle size volume distribution shows pronounced peaks in BNLs with active resuspension and in surface waters with active primary production. The aggregation rate of $1.5-8 \mu \mathrm{m}$ particles in the upper ocean depends on filtration by zooplankton. The fine mode in our data occurs within 3-8 $\mu \mathrm{m}$ and mostly in samples with low concentrations of about $0.01 \mathrm{ppm}$ (188 samples in total).

The upper ocean is the area where the particle production and modification of the initial size distributions occurs, controlled by turbulence. Increased shear in pycnoclines and internal wave-driven turbulence would promote aggregation and lead to a further smoothing of the size distribution (equivalent to a cumulative particle number distribution with a slope of -3 ) of SPM (McCave, 1984). The horizontal supply of SPM to the mid-water in the open ocean is relatively slow; therefore, a part of fine material in SPM is old (years old), so the size distribution should not have significant peaks. The flat size distributions are best explained by the sub-equal production of particles of different sizes. The coarse mode (20-60 $\mu \mathrm{m})$, according to McCave (1985), is a result of aggregation, where a significant role is played by mucus. Lately, as was mentioned above in the paper, mucus has started to be referred to as transparent exopolymer particles. There are no strong vertical gradients of mucus concentration suggesting a bottom source, so it is presumed that the material results from surface productivity and has settled rapidly. This viewpoint is supported in Emery and Honjo (1979), where the same type of material from surface waters is described and called an "(organic) film". It was shown that the film is most abundant in upwelling areas. The "left" part of the coarse mode was noticed within the "vertical anomaly", as well as in the BNLs (88 samples in total). The intermediate mode $(8-13 \mu \mathrm{m})$ was dominant in surface and intermediate waters $(50-3000 \mathrm{~m}$ depth) in the samples with high SPM levels $(0.3 \mathrm{ppm})$ ( 25 samples in total). Its occurrence is supposedly caused by high concentrations of phytoplankton with cell size less than $10 \mu \mathrm{m}$, as well as newborn transparent exopolymer particles and detritus. The vertical distribution of different fraction sizes of phytoplankton in the euphotic zone of the Equatorial Atlantic shows that the dominant plankton cell size at the $50 \mathrm{~m}$ depth is $3-20 \mu \mathrm{m}(11.5 \mu \mathrm{m}$ on average) (Herbland et al., 1985). This intermediate mode could not be revealed during the HEBBLE project, because the project was aimed exclusively at abyssal waters.

\section{Conclusions}

The Ioffe-2000 transect presented a "screenshot" of volume SPM distribution in the northern part of the Equatorial Atlantic against the background of hydrographic data. Alongside the general agreement with the three-layer model of the ocean SPM distribution, there were some large regional nonuniformities of SPM concentrations and grain size. The international studies of last two decades allowed us to explain those non-uniformities:

1. The most noticeable anomaly is a wide area of high SPM concentrations above the Sierra Leone Rise spread from the upper ocean, through the intermediate layer of clear water and down to the ocean bottom. We suggest that this "vertical anomaly" originated from the Northwest African upwelling area, where the aggregation process exists, since the plankton exposed to abundant Saharan dust form a large number of ballasted aggregates. The aggregates were later transported equatorward via the Canary Current and equatorial currents system (including the Guinea Dome). The vertical SPM concentration anomaly, revealed in our study, agrees with the fact that higher aggregate numbers and higher sinking velocities may increase the sediment transport to the bottom, and since the biogenic aggregates are rich in carbon, the carbon export to deep ocean layers will also increase.

2. Deep and bottom waters of the western part of the Equatorial Atlantic show increased levels of the SPM concentrations. The INL deepening from the American slope to the east was noted at depths of 3200-3700 m. The high SPM concentrations in the bottom layer above the Ceara Rise is caused by the interaction between the 
SPM-rich Deep Western Boundary Current and a local feature of bottom topography. Antarctic Bottom Water has increased SPM concentrations mostly in the 40$41^{\circ} \mathrm{W}$ troughs. The SPM maximum is located in the Antarctic Bottom Water core (4400-4500 m), separated from the bottom. The explanation for this may be that the bottom rise located up-stream serves as a "dam", blocking the lower part of Antarctic Bottom Water flow and its BNL.

3. The sizes of suspended particles in the cumulative number distribution follow a hyperbolic Junge distribution with slopes between -1.9 and -3.7 ; the averaged slope was approximated as -2.7 , which fits into the general understanding.

The volume-size distributions displayed two modes comparable to those found in HEBBLE: a fine-mode, 2$4 \mu \mathrm{m}$, and an increased proportion of the 7-21 $\mu \mathrm{m}$ fraction, suggesting the coarse mode $(20-60 \mu \mathrm{m})$. There was an additional intermediate mode, $8-13 \mu \mathrm{m}$. It is wellknown that the fine mode is mainly represented by aggregates formed from small particles by Brownian motion. The weakly pronounced fine mode could be suggesting a relatively old age of SPM and low concentrations. The coarse particles $(7-21 \mu \mathrm{m})$ likely represent aggregates with biogenic mucus (transparent exopolymer particles), which plays a significant role in particle aggregation. The additional intermediate mode (8$13 \mu \mathrm{m}$ ) is dominant in the SPM-rich surface waters and is presumably the result of phytoplankton growth and the initial transparent exopolymer particles formation.

Data availability. The coordinates (latitude, longitude) of the Ioffe2000 sampling stations, depths of samplings, and concentrations of particles (ppm by volume) are given in the Supplement. All other data used have been cited in the text.

Supplement. The supplement related to this article is available online at: https://doi.org/10.5194/os-17-1421-2021-supplement.

Author contributions. VS came up with the concept of the entire article, maintained the partial formal analysis and investigation, and provided supervision and financial acquisition. EB was in charge of data curation, visualization, and methodology along with partial formal analysis. All authors have read and agreed to the published version of the paper.

Competing interests. The contact author has declared that neither they nor their co-authors have any competing interests.
Disclaimer. Publisher's note: Copernicus Publications remains neutral with regard to jurisdictional claims in published maps and institutional affiliations.

Acknowledgements. The article was written in fond memory of academician Alexander P. Lisitsyn (IO RAS), who helped with this research. Marina Ulyanova and Leyla Bashirova contributed with valuable advice and fruitful discussions. Authors also would like to thank Ian Nicholas McCave, who definitely helped us improve the paper significantly.

Financial support. The preliminary data processing and surface ocean data interpretation were conducted with the financial support of the state assignment of IO RAS (theme 0128-2021-0016); the data interpretation and conclusions regarding the modern Antarctic Bottom Water circulation was supported by Russian Science Foundation (project 19-17-00246).

Review statement. This paper was edited by Mario Hoppema and reviewed by I. Nicholas McCave and one anonymous referee.

\section{References}

Alldredge, A. L., Passow, U., and Logan, B. E.: The abundance and significance of a class of large, transparent organic particles in the ocean, Deep-Sea Res. Pt. I, 40, 1131-1140, https://doi.org/10.1016/0967-0637(93)90129-Q, 1993.

Arhan, M., Mercier, H., Bourles, B., and Gouriou, Y.: Hydrographic sections across the Atlantic at $7^{\circ} 30 \mathrm{~N}$ and $4^{\circ} 30 \mathrm{~S}$, Deep-Sea Res. Pt. I, 45, 829-872, 1998.

Armi, L.: Mixing in the deep ocean: the importance of boundaries, Oceanus, 21, 14-19, 1978.

Armstrong, R. A., Lee, C., Hedges, J. I., Honjo, S., and Wakeham, S. G.: A new, mechanistic model for organic carbon fluxes in the ocean based on the quantitative association of POC with ballast minerals, Deep-Sea Res. Pt. II, 49, 219-236, https://doi.org/10.1016/S0967-0645(01)00101-1, 2001.

Barth, A., Alvera-Azcárate, A., Troupin, C., Ouberdous, M., and Beckers, J.-M.: A web interface for griding arbitrarily distributed in situ data based on Data-Interpolating Variational Analysis (DIVA), Adv. Geosci., 28, 29-37, https://doi.org/10.5194/adgeo28-29-2010, 2010.

Biscaye, P. E. and Eittreim, S. L.: Suspended particulate loads and transports in the nepheloid layer of the abyssal Atlantic Ocean, Mar. Geol., 23, 155-172, https://doi.org/10.1016/00253227(77)90087-1, 1977.

Bischof, B., Mariano, A. J., and Ryan, E. H.: The North Brazil Current, available at: https://oceancurrents.rsmas.miami. edu/atlantic/north-brazil.html (last access: 20 November 2020), 2003.

Bourlès, B., Gouriou, Y., and Chuchla, R.: On the circulation in the upper layer of the western equatorial Atlantic, J. Geophys. Res.-Oceans, 104, 21151-21170, https://doi.org/10.1029/1999JC900058, 1999. 
Bowden, K. F.: The dynamics of flow on a submarine ridge, Tellus, 12, 419-426, https://doi.org/10.3402/tellusa.v12i4.9415, 1960.

Brandt, P., Schott, F. A., Provost, C., Kartavtseff, A., Hormann, V., Bourlès, B., and Fischer, J.: Circulation in the central equatorial Atlantic: Mean and intraseasonal to seasonal variability, Geophys. Res. Lett., 33, L07609, https://doi.org/10.1029/2005GL025498, 2006.

Brandt, P., Hormann, V., Körtzinger, A., Visbeck, M., Krahmann, G., Stramma, L., Lumpkin, R., and Schmid, C.: Changes in the ventilation of the oxygen minimum zone of the tropical North Atlantic, J. Phys. Oceanogr., 40, 1784-1801, https://doi.org/10.1175/2010JPO4301.1, 2010.

Bressac, M., Guieu, C., Doxaran, D., Bourrin, F., Desboeufs, K., Leblond, N., and Ridame, C.: Quantification of the lithogenic carbon pump following a simulated dust-deposition event in large mesocosms, Biogeosciences, 11, 1007-1020, https://doi.org/10.5194/bg-11-1007-2014, 2014.

Brewer, P. G., Spencer, D. W., Biscaye, P. E., Hanley, A., Sachs, P. L., Smith, C. L., Kadar, S., and Fredericks, J.: The distribution of particulate matter in the Atlantic Ocean, Earth Planet. Sc. Lett., 32, 393-402, https://doi.org/10.1016/0012821X(76)90080-7, 1976.

Bruce, J., Kerling, J., and Beatty III, W.: On the North Brazilian eddy field, Prog. Oceanogr., 14, 57-63, https://doi.org/10.1016/0079-6611(85)90005-9, 1985.

Bubnova, E., Kapustina, M., Krechik, V., and Sivkov, V.: Suspended matter distribution in the surface layer of the East Equatorial Atlantic, Oceanology, 60, 228-235, https://doi.org/10.31857/S0030157420010049, 2020.

Burlakova, Z., Eremeeva, L., and Morozova, A.: Suspended matter in the estuaries of the Guinean shelf, Physical Oceanography, 8, 269-283, 1997.

Candela, J., Beardsley, R. C., and Limeburner, R.: Separation of tidal and subtidal currents in ship-mounted acoustic Doppler current profiler observations, J. Geophys. Res.-Oceans, 97, 769788, https://doi.org/10.1029/91JC02569, 1992.

Carder, K. L., Betzer, P. R., and Eggimann, D. W.: Physical, chemical, and optical measures of suspended-particle concentrations: their intercomparison and application to the West African Shelf, in: Suspended solids in water, edited by: Gibbs, R., Springer, Boston, MA, 173-193, 1974.

Chester, R.: Particulate material in the oceans, in: Marine Geochemistry, Springer, Dodrecht, 321-345, https://doi.org/10.1007/97894-010-9488-7_10, 1990.

Craig, H. and Turekian, K.: The GEOSECS program: 1973-1976, Earth Planet. Sc. Lett., 32, 217-219, https://doi.org/10.1016/0012-821X(76)90062-5, 1976.

Csanady, G.: "Pycnobathic" currents over the upper continental slope, J. Phys. Oceanogr., 15, 306-315, https://doi.org/10.1175/15200485(1985)015<0306:COTUCS>2.0.CO;2, 1985.

Didden, N. and Schott, F.: Eddies in the North Brazil Current retroflection region observed by Geosat altimetry, J. Geophys. Res.-Oceans, 98, 20121-20131, https://doi.org/10.1029/93JC01184, 1993.

Doi, T., Tozuka, T., and Yamagata, T.: Interannual variability of the Guinea Dome and its possible link with the Atlantic Meridional Mode, Clim. Dynam., 33, 985-998, https://doi.org/10.1007/s00382-009-0574-z, 2009.
Egloff, J.: Morphology of ocean basin seaward of northwest Africa: Canary Islands to Monrovia, Liberia, AAPG Bull., 56, 694-706, 1972.

Eittreim, S., Thorndike, E. M., and Sullivan, L.: Turbidity distribution in the Atlantic Ocean, Deep Sea Research and Oceanographic Abstracts, 23, 1115-1127, https://doi.org/10.1016/00117471(76)90888-3, 1976.

Eittreim, S. L. and Ewing, M.: Turbidity distribution in the deep waters of the western Atlantic trough, in: Suspended solids in water, edited by: Gibbs, R., Springer, Boston, MA, 213-225, 1974.

Emelyanov, E. M.: The barrier zones in the ocean, Springer Science and Business Media, Berlin, Heideberg, 2005.

Emery, K. and Honjo, S.: Surface suspended matter off western Africa: relations of organic matter, skeletal debris and detrital minerals, Sedimentology, 26, 775-794, https://doi.org/10.1111/j.1365-3091.1979.tb00972.x, 1979.

Fratantoni, D. M., Johns, W. E., and Townsend, T. L.: Rings of the North Brazil Current: Their structure and behavior inferred from observations and a numerical simulation, J. Geophys. Res.Oceans, 100, 10633-10654, https://doi.org/10.1029/95JC00925, 1995.

Gardner, W. D., Biscaye, P. E., Zaneveld, J. R. V., and Richardson, M. J.: Calibration and comparison of the LDGO nephelometer and the OSU transmissometer on the Nova Scotian Rise, Mar. Geol., 66, 323-344, https://doi.org/10.1016/00253227(85)90037-4, 1985a.

Gardner, W. D., Southard, J. B., and Hollister, C. D.: Sedimentation, resuspension and chemistry of particles in the northwest Atlantic, Mar. Geol., 65, 199-242, https://doi.org/10.1016/00253227(85)90057-X, 1985b.

Gardner, W. D., Richardson, M. J., Mishonov, A. V., and Biscaye, P. E.: Global comparison of benthic nepheloid layers based on 52 years of nephelometer and transmissometer measurements, Prog. Oceanogr., 168, 100-111, https://doi.org/10.1016/j.pocean.2018.09.008, 2018.

GEBCO Bathymetric Compilation Group: The GEBCO_2020 Grid - a continuous terrain model of the global oceans and land, https://doi.org/10.5285/a29c5465-b138-234d-e0536c86abc040b9, 2020.

Gibbs, R. J.: The suspended material of the Amazon shelf and tropical Atlantic Ocean, in: Suspended solids in water, edited by: Gibbs, R., Springer, Boston, MA, 203-210, https://doi.org/10.1007/978-1-4684-8529-5_1, 1974.

Herbland, A., Le Bouteiller, A., and Raimbault, P.: Size structure of phytoplankton biomass in the equatorial Atlantic Ocean, Deep-Sea Res. Pt. I, 32, 819-836, https://doi.org/10.1016/01980149(85)90118-9, 1985.

Iversen, M. H. and Ploug, H.: Ballast minerals and the sinking carbon flux in the ocean: carbon-specific respiration rates and sinking velocity of marine snow aggregates, Biogeosciences, 7 , 2613-2624, https://doi.org/10.5194/bg-7-2613-2010, 2010.

Jeandel, C., Rutgers van der Loeff, M., Lam, P. J., RoyBarman, M., Sherrell, R. M., Kretschmer, S., German, C., and Dehairs, F.: What did we learn about ocean particle dynamics in the GEOSECS-JGOFS era?, Prog. Oceanogr., 133, 6-16, https://doi.org/10.1016/j.pocean.2014.12.018, 2015.

Johns, W. E., Lee, T., Beardsley, R., Candela, J., Limeburner, R., and Castro, B.: Annual cycle and variability of the North Brazil Current, J. Phys. 
Oceanogr., $\quad 28, \quad 103-128, \quad$ https://doi.org/10.1175/15200485(1998)028<0103:ACAVOT>2.0.CO;2, 1998.

Karstensen, J., Stramma, L., and Visbeck, M.: Oxygen minimum zones in the eastern tropical Atlantic and Pacific oceans, Prog. Oceanogr., 77, 331-350, https://doi.org/10.1016/j.pocean.2007.05.009, 2008.

Lal, D.: The oceanic microcosm of particles, Science, 198, 9971009, https://doi.org/10.1126/science.198.4321.997, 1977.

Lavelle, J.: On the dynamics of current jets trapped to the flanks of mid-ocean ridges, J. Geophys. Res.-Oceans, 117, C07002, https://doi.org/10.1029/2011JC007627, 2012.

Lázaro, C., Fernandes, M. J., Santos, A. M. P., and Oliveira, P.: Seasonal and interannual variability of surface circulation in the Cape Verde region from 8 years of merged T/P and ERS-2 altimeter data, Remote Sens. Environ., 98, 45-62, https://doi.org/10.1016/j.rse.2005.06.005, 2005.

Louis, J., Pedrotti, M. L., Gazeau, F., and Guieu, C.: Experimental evidence of formation of transparent exopolymer particles (TEP) and POC export provoked by dust addition under current and high $p \mathrm{CO}_{2}$ conditions, PloS one, 12, e0171980, https://doi.org/10.1371/journal.pone.0171980, 2017.

Mayer, D. A. and Weisberg, R. H.: A description of COADS surface meteorological fields and the implied Sverdrup transports for the Atlantic Ocean from $30^{\circ} \mathrm{S}$ to $60^{\circ} \mathrm{N}$, J. Phys. Oceanogr., 23, 2201-2221, https://doi.org/10.1175/15200485(1993)023<2201:ADOCSM>2.0.CO;2, 1993.

Mazarovich, A. and Sokolov, S. Y.: Hydrothermal fields in the MidAtlantic Ridge: Setting and prospects for further discoveries, Russian Journal of Earth Sciences, 4, 423-431, 2002.

McCartney, M., Bennett, S., and Woodgate-Jones, M.: Eastward flow through the Mid-Atlantic Ridge at $11^{\circ} \mathrm{N}$ and its influence on the abyss of the eastern basin, J. Phys. Oceanogr., 21, 1089-1121, https://doi.org/10.1175/15200485(1991)021<1089:EFTTMA>2.0.CO;2, 1991.

McCartney, M. S.: Crossing of the equator by the deep western boundary current in the western Atlantic Ocean, J. Phys. Oceanogr., 23, 1953-1974, https://doi.org/10.1175/15200485(1993)023<1953:COTEBT>2.0.CO;2, 1993.

McCave, I.: Vertical flux of particles in the ocean, Deep Sea Research and Oceanographic Abstracts, 22, 491-502, https://doi.org/10.1016/0011-7471(75)90022-4, 1975.

McCave, I.: Particulate size spectra, behavior, and origin of nepheloid layers over the Nova Scotian continental rise, J. Geophys. Res.-Oceans, 88, 7647-7666, https://doi.org/10.1029/JC088iC12p07647, 1983.

McCave, I.: Size spectra and aggregation of suspended particles in the deep ocean, Deep-Sea Res. Pt. I, 31, 329-352, https://doi.org/10.1016/0198-0149(84)90088-8, 1984.

McCave, I.: Properties of suspended sediment over the HEBBLE area on the Nova Scotian Rise, Mar. Geol., 66, 169-188, https://doi.org/10.1016/0025-3227(85)90028-3, 1985.

McCave, I.: Local and global aspects of the bottom nepheloid layers in the world ocean, Neth. J. Sea Res., 20, 167-181, https://doi.org/10.1016/0077-7579(86)90040-2, 1986.

McCave, I., Hall, I. R., Antia, A., Chou, L., Dehairs, F., Lampitt, R., Thomsen, L., Van Weering, T., and Wollast, R.: Distribution, composition and flux of particulate material over the European margin at 47-50 N, Deep-Sea Res. Pt. II, 48, 3107-3139, https://doi.org/10.1016/S0967-0645(01)00034-0, 2001.
Mittelstaedt, E.: The ocean boundary along the northwest African coast: Circulation and oceanographic properties at the sea surface, Prog. Oceanogr., 26, 307-355, https://doi.org/10.1016/0079-6611(91)90011-A, 1991.

Molinari, R. L., Fine, R. A., and Johns, E.: The deep western boundary current in the tropical North Atlantic Ocean, DeepSea Res. Pt. I, 39, 1967-1984, https://doi.org/10.1016/01980149(92)90008-H, 1992.

Morozov, E. G.: Oceanic Internal Tides: Observations, Analysis and Modeling, Springer International Publishing, Cham, https://doi.org/10.1007/978-3-319-73159-9, 2018.

Mullin, J. and Riley, J.: The colorimetric determination of silicate with special reference to sea and natural waters, Anal. Chim. Acta, 12, 162-176, 1955.

Nowell, A., McCave, I., and Hollister, C.: Contributions of HEBBLE to understanding marine sedimentation, Mar. Geol., 66, 397-409, https://doi.org/10.1016/0025-3227(85)90041-6, 1985.

Oudot, C., Ternon, J.-F., Andrié, C., Braga, E. S., and Morin, P.: On the crossing of the equator by intermediate water masses in the western Atlantic Ocean: Identification and pathways of Antarctic Intermediate Water and Upper Circumpolar Water, J. Geophys. Res.-Oceans, 104, 20911-20926, https://doi.org/10.1029/1999JC900123, 1999.

Passow, U.: Transparent exopolymer particles (TEP) in aquatic environments, Prog. Oceanogr., 55, 287-333, https://doi.org/10.1016/S0079-6611(02)00138-6, 2002.

Passow, U. and Alldredge, A.: Distribution, size and bacterial colonization of transparent exopolymer particles (TEP) in the ocean, Mar. Ecol. Prog. Ser., 113, 185-198, 1994.

Passow, U., Shipe, R., Murray, A., Pak, D., Brzezinski, M., and Alldredge, A.: The origin of transparent exopolymer particles (TEP) and their role in the sedimentation of particulate matter, Cont. Shelf Res., 21, 327-346, https://doi.org/10.1016/S02784343(00)00101-1, 2001.

Peterson, R. G. and Stramma, L.: Upper-level circulation in the South Atlantic Ocean, Prog. Oceanogr., 26, 1-73, https://doi.org/10.1016/0079-6611(91)90006-8, 1991.

Petschick, R., Kuhn, G., and Gingele, F.: Clay mineral distribution in surface sediments of the South Atlantic: sources, transport, and relation to oceanography, Mar. Geol., 130, 203-229, https://doi.org/10.1016/0025-3227(95)00148-4, 1996.

Pradhan, Y., Lavender, S. J., Hardman-Mountford, N. J., and Aiken, J.: Seasonal and inter-annual variability of chlorophylla concentration in the Mauritanian upwelling: Observation of an anomalous event during 1998-1999, Deep-Sea Res. Pt. II, 53, 1548-1559, https://doi.org/10.1016/j.dsr2.2006.05.016, 2006.

Reid, J. L.: On the total geostrophic circulation of the North Atlantic Ocean: Flow patterns, tracers, and transports, Prog. Oceanogr., 33, 1-92, https://doi.org/10.1016/0079-6611(89)90001-3, 1994.

Reid, J. L.: On the total geostrophic circulation of the Pacific Ocean: Flow patterns, tracers, and transports, Prog. Oceanogr., 39, 263352, https://doi.org/10.1016/S0079-6611(97)00012-8, 1997.

Rhein, M., Stramma, L., and Krahmann, G.: The spreading of Antarctic bottom water in the tropical Atlantic, Deep-Sea Res. Pt. I, 45, 507-527, https://doi.org/10.1016/S0967-0637(97)00030-7, 1998.

Richardson, P., Hufford, G., Limeburner, R., and Brown, W.: North Brazil current retroflection eddies, J. Geophys. Res.-Oceans, 99, 5081-5093, https://doi.org/10.1029/93JC03486, 1994. 
Rossignol, M. and Meyrueis, A.: Campagnes oceanographiques du Gerad-Treca, Cent. Oceanogr. Dakar-Thiaroye, ORSTOM, Dakar, Senegal, 53, 1964.

Sarafanov, A., Sokov, A., and Demidov, A.: Water mass characteristics in the equatorial North Atlantic: A section nominally along $6.5^{\circ} \mathrm{N}$, July 2000, J. Geophys. Res.-Oceans, 112, C12023, https://doi.org/10.1029/2007JC004222, 2007.

Schlitzer, R.: Ocean Data View, available at: https://odv.awi.de/ (last access: 31 August 2021), 2018.

Schott, F. A., Brandt, P., Hamann, M., Fischer, J., and Stramma, L.: On the boundary flow off Brazil at $5-10^{\circ} \mathrm{S}$ and its connection to the interior tropical Atlantic, Geophys. Res. Lett., 29, 1840, https://doi.org/10.1029/2002GL014786, 2002.

Sheldon, R., Prakash, A., and Sutcliffe Jr., W.: The size distribution of particles in the ocean 1, Limnol. Oceanogr., 17, 327-340, https://doi.org/10.4319/lo.1972.17.3.0327, 1972.

Siedler, G., Zangenberg, N., Onken, R., and Morlière, A.: Seasonal changes in the tropical Atlantic circulation: Observation and simulation of the Guinea Dome, J. Geophys. Res.-Oceans, 97, 703715, https://doi.org/10.1029/91JC02501, 1992.

Signorini, S., Murtugudde, R., McClain, C., Christian, J., Picaut, J., and Busalacchi, A.: Biological and physical signatures in the tropical and subtropical Atlantic, J. Geophys. Res.-Oceans, 104, 18367-18382, https://doi.org/10.1029/1999JC900134, 1999.

Sivkov, V., Zhurov, Y., and Demidova, T.: A new data on the distribution of suspended matter in the North Atlantic, in: Proceedings of the XIV School of Marine geology, vol. 2, 172-173, IO RAN, 2001 (in Russian).

Smith, K., Williams, P., and Druffel, E.: Upward fluxes of particulate organic matter in the deep North Pacific, Nature, 337, 724726, https://doi.org/10.1038/337724a0, 1989.

Sokov, A., Morozov, E., Shapovalov, S., Borodkin, S., and Demidova, T.: Water structure in the equatorial Atlantic on the basis of the year 2000 transatlantic section, Oceanology, 42, 1-6, 2002.

Stramma, L. and Schott, F.: The mean flow field of the tropical Atlantic Ocean, Deep-Sea Res. Pt. II, 46, 279-303, https://doi.org/10.1016/S0967-0645(98)00109-X, 1999.

Stramma, L., Rhein, M., Brandt, P., Dengler, M., Böning, C., and Walter, M.: Upper ocean circulation in the western tropical Atlantic in boreal fall 2000, Deep-Sea Res. Pt. I, 52, 221-240, https://doi.org/10.1016/j.dsr.2004.07.021, 2005.
Stramma, L., Brandt, P., Schafstall, J., Schott, F., Fischer, J., and Körtzinger, A.: Oxygen minimum zone in the North Atlantic south and east of the Cape Verde Islands, J. Geophys. Res.Oceans, 113, C04014, https://doi.org/10.1029/2007JC004369, 2008.

Thorpe, S. and White, M.: A deep intermediate nepheloid layer, Deep-Sea Res. Pt I, 35, 1665-1671, https://doi.org/10.1016/0198-0149(88)90109-4, 1988.

Touratier, F., Goyet, C., Coatanoan, C., and Andrié, C.: Assessments of anthropogenic $\mathrm{CO}_{2}$ distribution in the tropical Atlantic Ocean, Deep-Sea Res. Pt. I, 52, 2275-2284, 2005.

Tucholke, B. E. and Eittreim, S.: The western boundary undercurrent as a turbidity maximum over the Puerto Rico Trench, J. Geophys. Res., 79, 4115-4118, 1974.

Turekian, K. K.: The fate of metals in the oceans, Geochim. Cosmochim. Ac., 41, 1139-1144, https://doi.org/10.1016/00167037(77)90109-0, 1977.

Van der Jagt, H., Friese, C., Stuut, J.-B. W., Fischer, G., and Iversen, M. H.: The ballasting effect of Saharan dust deposition on aggregate dynamics and carbon export: Aggregation, settling, and scavenging potential of marine snow, Limnol. Oceanogr., 63, 1386-1394, https://doi.org/10.1002/lno.10779, 2018.

Vladimirov, V., Bezborodov, A., Martynov, O., Ovsyanyi, E., and Diallo, B.: Relation between the depth of visibility of a white disk and the concentration of suspended matter in shelf waters off the Republic of Guinea, Soviet J. Phys. Oceanogr., 1, 469474, 1990.

Whitehead Jr., J. and Worthington, L.: The flux and mixing rates of Antarctic Bottom Water within the North Atlantic, J. Geophys. Res.-Oceans, 87, 7903-7924, https://doi.org/10.1029/JC087iC10p07903, 1982.

Wilson, W. D., Johns, E., and Molinari, R.: Upper layer circulation in the western tropical North Atlantic Ocean during August 1989, J. Geophys. Res.-Oceans, 99, 22513-22523, https://doi.org/10.1029/94JC02066, 1994.

Wüst, G.: Schichtung und Zirkulation des Atlantischen Ozeans, Wiss. Erg., 6, 288, 1935. 